\title{
Fleksibilitas Pajak sebagai Instrumen Kebijaksanaan Fiskal untuk Mengantisipasi Krisis Ekonomi sebagai Akibat Dampak Pandemi Covid-19
}

\author{
F.C. Susila Adiyanta \\ Fakultas Hukum Universitas Diponegoro \\ Jln. Prof Soedarto, S.H., Tembalang, Semarang \\ susilafhundip@gmail.com \\ susilaadiyanta@lecturer.undip.ac.id
}

\begin{abstract}
Abstrak
Penelitian ini bertujuan untuk menelaah tentang pengalaman Indonesia sebagai negara yang telah mampu mengatasi dan melampaui krisis finansial dengan menggunakan strategi kebijakan fiskal yang baik dan kebijakan pembaruan perpajakan nasional melalui reformasi regulasi dan administrasi perpajakan modern. Pengalaman mengatasi krisis finansial tersebut menjadi bahan pembelajaran yang menarik bagi Pemerintah untuk membuat kebijakan antisipatif untuk menghadapi dampak ekonomi finansial dan moneter akibat pandemi Covid-19. Metode pendekatan sosiolegal digunakan untuk dapat mendeskripsikan secara mendalam penggunaan pajak sebagai salah satu instrumen kebijakan fiskal dalam praksis perpajakan nasional. Hasil penelitian ini adalah: a) fungsi pajak sebagai instrumen kebijakan fiskal dengan kombinasi fungsi mengatur (regulerend) dan stabilitasi ekonomi untuk menjaga kondisi kontraksi dan relaksasi ekonomi nasional, mempunyai fleksibilitas untuk penerimaan negara (budgetair) yang berkelanjutan (sustainable budged income; b) fungsi alokasi anggaran belanja negara untuk biaya pemerintah dan kepentingan umum yang seimbang, distribusi untuk kesejahteraan masyarakat dengan tetap menjaga stabilitasi pertumbuhan ekonomi yang mendukung pembangunan nasional merupakan salah satu faktor penentu keberhasilan kebijaksanaan fiskal dalam meningkatkan daya saing investasi dan mengantisipasi pelemahan ekonomi global;
\end{abstract}

Kata kunci: Pajak, Kebijaksanaan Fiskal, Daya Saing Investasi, Satbilitas Ekonomi Nasional

\begin{abstract}
This research aims to examine the experience of Indonesia as a country that has been able to overcome and surpass the financial crisis by using a good fiscal policy strategy and national tax reform policy through modern taxation and regulatory reform. The sociolegal approach method is used to be able to describe deeply the use of tax as one of the instruments of fiscal policy in the practice of national taxation. The conclusions of the results of this study are: a) the function of tax as an instrument of fiscal policy, with a
\end{abstract}


combination of the function of regulating (regularend) and economic stabilization to maintain the conditions of contraction and relaxation of the national economy, having flexibility for sustainable state budget (sustainable budget); b) the function of the allocation of the state budget for government costs and balanced public interests, distribution for the welfare of the community while maintaining the stabilization of economic growth that supports national development is one of the determining factors for the success of fiscal policy in increasing investment competitiveness and anticipating the weakening of the global economy;

Keywords: Tax, Fiscal Policy, Investment Competitiveness, National Economy Stability

\section{A. Pendahuluan}

Pandemi Covid-19 melanda hanmpir semua negara di dunia, tidak terkecuali Negara Indonesia. Kesiapan dan ketahanan sosial, ekonomi, politik dan keamanan nasional semua negara diuji untuk mengatasi berbagai dampak yang timbul dari pandemi. Dalam konteks komunitas dunia, Indonesia sebagai negara modern tidak bisa lepas dari pengaruh dan kerja sama dengan negara-negara di seluruh dunia. Kerja sama dengan berbagai negara yang saling menguntungkan sangat membantu bagi negara Indonesia dalam mewujudkan tujuan memajukan kehidupan bangsa dan kesejahteraan umum. Pada sisi lain, kondisi finansial Indonesia rentan dipengaruhi kondisi ekonomi global yang mengalami kelesuan, bahkan kemandegan yang tidak bisa diprediksi sebelumnya.

Seperti halnya dengan kondisi ekonomi global yang terjadi saat ini, perang dagang berkepanjangan antara dua raksasa ekonomi dunia, Amerika dan Tingkok, telah mempengaruhi kondisi ekonomi hampir semua negara yang menjalin relasi dagang dengan kedua negara tersebut. Disusul kemudian dengan adanya wabah global pandemi Covid-19 yang melanda hanpir semua negara, kebijakan Amerika Serikat (AS) yang ketat terhadap negara Tiongkok sebagai pesaing utamanya, membuat ekonomi dunia menjadi tidak ramah. (Harian Kompas; 2020)

Berbagai kebijakan ekonomi yang membuat gejolak di antaranya kenaikan suku bunga acuan AS yang lebih cepat dan tinggi, dan perang dagang AS-Tiongkok. Perang dagang antara Amerika Serikat (AS) dan Tiongkok membuat seluruh pihak menderita, termasuk Indonesia. Sengketa dagang AS-Tiongkok semakin panas dalam beberapa bulan terakhir dan kelihatan semakin berlanjut, mengingat adanya beberapa pernyataan yang 
tetap memanas diantara kedua Pemimpin Negara. AS menaikkan bea impor produk dari Tiongkok dari $10 \%$ menjadi $25 \%{ }^{1}$.

Tabel 1.

Proyeksi Pertumbuhan Ekonomi Global Versi OECD

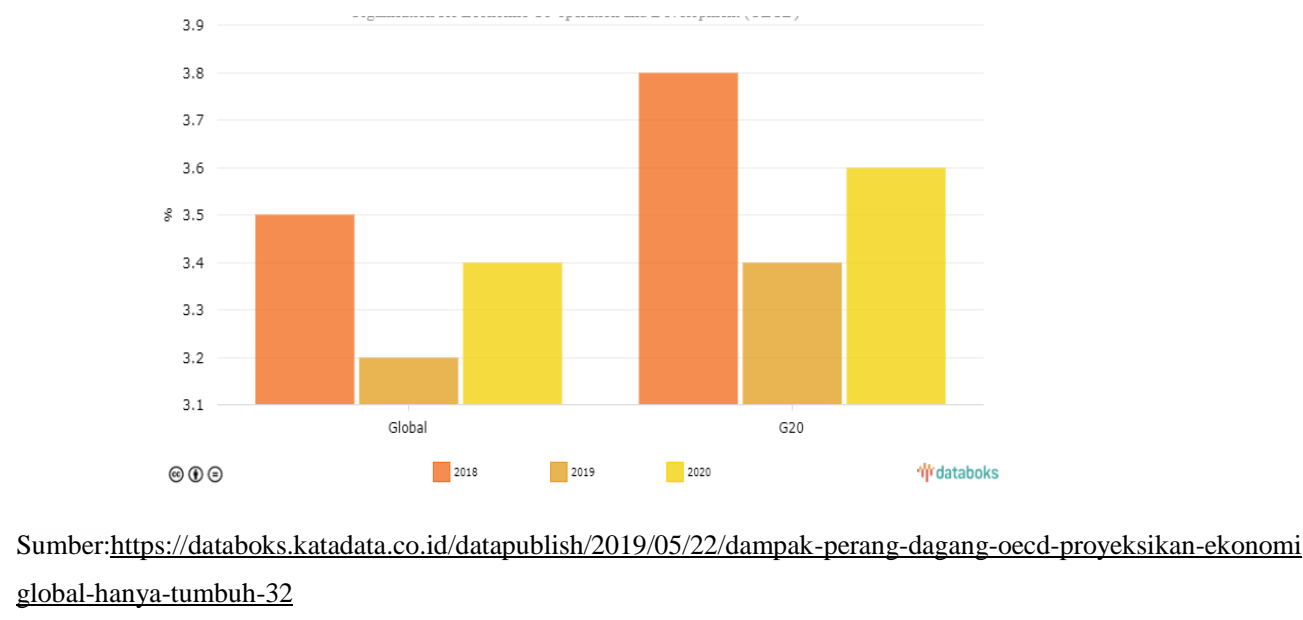

Pemerintah Beijing membalasnya dengan menaikkan tarif impor terhadap 5.140 produk AS senilai Rp 60 miliar dari 5-10\% menjadi 25\%. Akibat perang dagang, pertumbuhan ekonomi global menyusut, seperti perkiraan terbaru dari Organisasi untuk Kerja Sama dan Pembangunan Ekonomi (OECD) (Kata Data; 2020)². Sebelumnya, OECD memproyeksikan pertumbuhan ekonomi global pada 2019 hanya mencapai 3,2\%. Angka ini lebih rendah dibandingkan pertumbuhan ekonomi global 2018 sebesar 3,5\%. OECD menyebut perang dagang yang berlarut-larut antara Amerika Serikat dan Tiongkok menjadi penyebab perlambatan pertumbuhan ekonomi global ${ }^{3}$.

Pada hakikatnya, masa depan tak pernah bisa dipahami dengan pasti. Manajemen risiko paling maju sekalipun hanya mampu meminimalkan ketidakpastian, tak pernah bisa menghilangkan. Begitu juga potensi resesi global 2020, menyimpan begitu banyak pertanyaan bagi banyak negara, termasuk pula bagi negara Indonesia. Bank Dunia dalam paparan "Global Economic Risks and Implications for Indonesia" menjelaskan, dampak krisis global terhadap Indonesia tak akan separah Turki, Argentina, dan negara-negara lain yang sudah lebih dari dua triwulan mengalami pelambatan pertumbuhan ekonomi. Risiko

\footnotetext{
${ }^{1}$ A Prasetyantoko, “Analisis Ekonomi: Analisis Ekonomi Memahami Transmisi Krisis” dikutip dari laman https://Kompas.Id/Baca/Utama/2019/09/10/Memahami-Transmisi-Krisis/

${ }^{2}$ https://katadata.co.id/berita/2019/05/23/menko-darmin-semua-menderita-akibat-perang-dagang

3 Prasetyantoko, loc.cit.
} 
paling besar adalah pelarian modal dari pasar keuangan, dengan potensi kembali meskipun porsinya lebih kecil. Jadi, dampak jangka pendeknya relatif terkendali. Bank Dunia justru lebih mengkhawatirkan dampak jangka menengah, yang jika tak dimitigasi berpotensi menyeret pertumbuhan melemah hingga 4,6 persen pada $2021^{4}$.

Dengan memperhatikan kondisi riil dan prediksi stagnasi pertumbuhan ekonomi dan moneter yang akan dihadapi oleh Indonesia sebagai dampak dari pandemi Covid-19, maka menjadi menarik untuk mengkaji tentang bagaimana kesiapan negara dalam menghadapi dan mengantisipasi krisis finansial global melalui perspektif kebijakan fiskal nasional dengan fungsi pajak sebagai instrumen yang mempunyai fleksibilitas untuk penerimaan negara (budgetair) yang berkelanjutan (sustainable budged income), dengan kombinasi fungsi mengatur (regulerend) dan stabilitas ekonomi untuk menjaga kondisi kontraksi dan relaksasi ekonomi nasional, jika terjadi gejolak yang tidak seimbang bahkan bila cenderung menjadi tidak sehat.

Kebijakan pembaruan perpajakan nasional yang telah dirancang dengan baik oleh Pemerintah pada dasarnya dapat berkontribusi dalam mendukung pembiayaan nasional melalui reformasi regulasi dan administrasi perpajakan modern dengan kebijakan dalam praksis perpajakan yang mengkombinasikan fungsi-fungsi pajak yang saling bersinergi dengan baik. Melalui studi tentang urgensi pajak sebagai instrumen kebijakan fiskal, diharapkan dapat menjadi bahan pembelajaran untuk membuat kebijakan bagi Pemerintah sebagai pihak yang mempunyai otoritas dalam mengantisipasi kemungkinan terjadinya krisis ekonomi sebagai akibat dampak pandemi covid-19.

Dengan berdasarkan studi tentang fungsi pajak dalam kebijakan fiskal ini, pemerintah dapat melakukan refleksi dan evaluasi dalam membuat kebijakan yang tepa untuk melakulan pemulihan ekonomi nasional, mampu mengundang investasi dari para pemilik modal, dan memenangkan persaingan ekonomi dengan negara-negara lain yang juga sedang mengalami kelesuan ekonomi karena dampak pandemi global Covid-19

Dengan berdasarkan deskripsi tentang latar belakang masalah yang telah dijelaskan di alinea-alinea di atas, fokus kajian artikel dengan topik "Fleksibilitas Pajak sebagai Instrumen Kebijaksanaan Fiskal untuk Mengantisipasi Krisis Ekonomi sebagai Akibat Dampak Pandemi Covid-19” ini adalah untuk menelaah tentang pengalaman

${ }^{4}$ Prasetyantoko, loc.cit. 
Indonesia sebagai negara yang telah mampu mengatasi dan melampaui krisis finansial dengan menggunakan strategi kebijakan fiskal yang baik dan valid.

\section{B. Rumusan Masalah}

Berdasarkan uraikan latar belakang penelitian, deskripsi rumusan masalah yang menjadi fokus bahasan artikel ini adalah: 1). Bagaimana pengalaman kebijakan fiskal negara Indonesia pada masa krisis ekonomi global dan apakah kebijakan fiskal tersebut dapat diadopsi untuk ditransiformasikan sebagai strategi dalam mengantisipasi dampak pandemi covid-19 yang saat ini sedang terjadi ? 2). Bagaimana keberlanjutan kebijakan pembaruan sistem perpajakan nasional sebagai sumber utama bagi stabilisasi ekonomi dan penerimaan negara yang bekelanjutan (renewable revenue resources) untuk mengantisipasi dampak pandemi covid-19 yang saat ini sedang terjadi ? 3). Bagaimana sinergi fungsi pajak sebagai instrumen kebijakan fiskal dalam menjaga stabilitasi daya saing investasi dan ketahanan ekonomi nasional di tengah pandemi covid-19?

\section{Pembahasan}

\section{Pengalaman Stabilitasi Finansial Indonesia pada Masa Krisis Ekonomi Global: Strategi Kebijakan Fiskal untuk Mengantisipasi Dampak Pandemi Covid-19}

Wabah pandemi Covid-19 yang melanda hampir semua negara-negara di dunia, telah meluluhlantakkan tatanan kehidupan seluruh warga masyarakat dunia. Banyak negara harus merencanakan ulang berbagai kebijakan ekonomi, moneter dan pembangunan nasionalnya. Negara maupun badan-badan swasta dipaksa merencanakan ulang berbagai prioritas ekonomi dan finansial, mengalokasikan kembali berbagai sumber daya untuk menghadapi dampak wabah pandemi Covid-19. Kondisi darurat bencana ini telah mendorong banyak pemimpin negara-negara di dunia untuk merefleksi ulang pengalamannya dalam mengatasi krisis finansial yang sudah pernah terjadi dan melanda hampir semua negara.

Pada periode tahun 1996 hingga tahun 1998, Indonesia mengalami krisis ekonomi sebagai imbas dari krisis ekonomi global. Setelah melewati periode yang sangat berat akibat krisis finansial dan ekonomi pada tahun 1998, perekonomian Asia Pasifik, termasuk pula Indonesia akhirnya mulai dapat bernafas lega. Pacific Economic Corporation Council (PECC) meyakini bahwa tahun 1999 adalah merupakan tahun pemulihan bagi 
perekonomian negara-negara di kawasan Asia. Namun demikian, sejumlah risiko masih tetap menghadang dan menyeret kembali negara-negara tersebut ke dalam krisis yang lebih buruk, Dalam laporan terbarunya berjudul “Pacific Economic Outlook (PEO) 1999-2000”, PECC sepakat bahwa krisis telah lewat dan perekonomian 19 (sembilan belas) negaranegara di kawasan Asia tersebut sudah mulai bangkit kembali. ${ }^{5}$

Kesembilan belas negara yang menjadi obyek penelitian PEO tersebut adalah Australia, Kanada, Cile, Cina, Kolumbia, Hongkong, Indonesia, Jepang, Korea Selatan, Malaysia, Meksiko, Selandia Baru, Peru, Filipina, Singapura, Thailand, Amerika Serikat, dan Vietnam. Indonesia termasuk salah satu negara yang dikecualikan. Dalam hal ini Indonesia dinilai agak tertinggal dan diperkirakan baru akan mengalami titik balik ekonomi pada paruh kedua tahun 1999. Dari ke 19 negara yang diteliti PEO tersebut, hanya Indonesia dan Hongkong yang masih akan mengalami pertumbuhan ekonomi negatif pada tahun $1999^{6}$.

\section{Grafik 1}

Pertumbuhan ekonomi Negara-negara Pasca Krisis Ekonomi Global 1980-2015

Versi Pacific Economic Corporation Council (PECC)

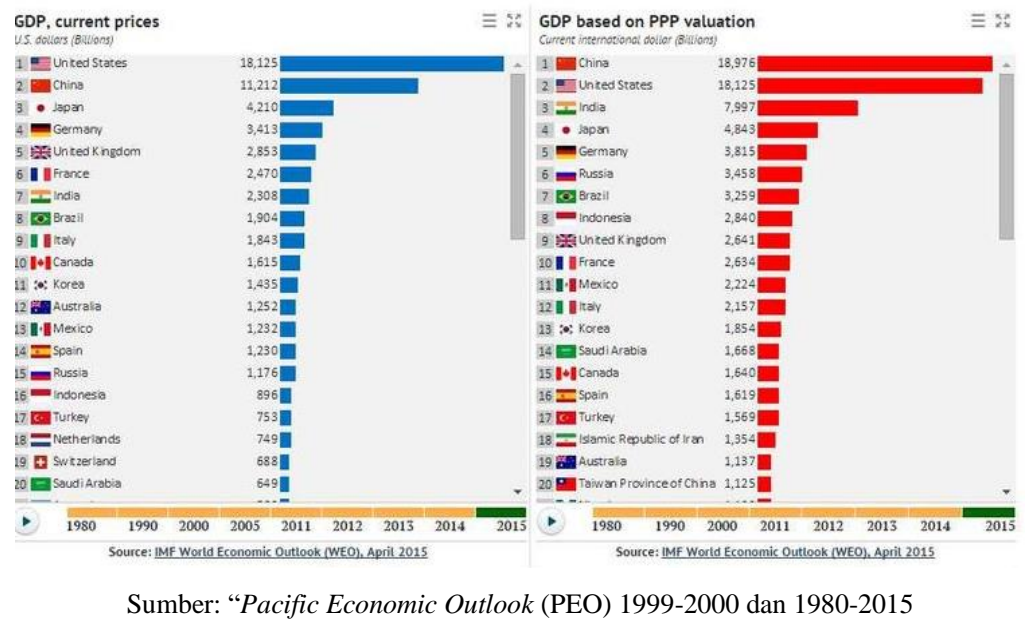

Setelah resesi terburuk dalam 35 tahun terakhir, yang ditandai dengan pertumbuhan minus 13,1 persen tahun 1998, perekonomian Indonesia diperkirakan masih akan terkontraksi lagi sebesar 2,5 persen tahun 1999, dan baru akan mengalami titik balik (turning point) ekonomi pada paruh kedua tahun 1999. Selanjutnya baru tahun 2000, 
perekonomian Indonesia akan mencatat pertumbuhan positif 3,7 persen. Setelah itu, Indonesia diperkirakan akan pulih ke pertumbuhan berkesinambungan (sustainable) dalam jangka panjang mulai tahun 2001, sebesar sekitar 5 persen per tahun ${ }^{7}$.

Pemulihan ekonomi Indonesia sulit diharapkan dapat terjadi secepat beberapa negara tetangganya, seperti Korea Selatan dan Thailand. Ekonom Suhadi Mangkusuwondo, Hadi Soesastro, dan Ari Kuncoro menyebut tidak segera tuntasnya langkah restrukturisasi sektor finansial, merupakan salah satu penyebab utama ketertinggalan Indonesia dalam pemulihan ekonomi dibandingkan dengan negara-negara tetangga lainnya. Bank Dunia dalam salah satu laporannya misalnya, menyebutkan pencairan dana IMF yang lambat dan seret untuk Indonesia adalah karena negara ini sangat lambat membuat kemajuan dalam restrukturisasi perbankan dan restrukturisasi utang. ${ }^{8}$

Selain itu, pertumbuhan ekonomi yang lebih banyak mengandalkan akumulasi modal serta tenaga kerja dan bukan peningkatan produktifitas, juga turut menyumbang pada ketertinggalan Indonesia dalam pemulihan. Di Indonesia, banyak industri bahkan dipaksa beroperasi pada level tidak sampai $50 \%$ dari kapasitas produksinya. Kondisi ini diperburuk lagi dengan adanya ketidakpastian politik dan kevakuman pemerintahan sehingga sulit untuk bisa mengambil keputusan-keputusan ekonomi yang penting dalam upaya pemulihan ekonomi. Demikian pula adanya pelarian modal asing maupun domestik yang angkanya mencapai 28 miliar dollar AS pada semester pertama tahun 1998 saja. Dari jumlah tersebut, delapan miliar dollar AS adalah modal milik warga Indonesia. ${ }^{9}$

Adanya krisis ekonomi yang berkepanjangan dan mengimbas pada runtuhnya rejim Orde Baru mempunyai pengaruh pada kondisi sosial politik dalam negeri. Demikian pula pengaruh tersebut nampak pula dalam peringkat daya saing Indonesia secara global dibandingkan dengan negara-negara lainnya. Menurut "The 1999 Global Competitieveness Report" yang dipublikasikan World Economic Forum (WEF), di Geneva, tanggal 13 Juli 1999. Peringkat daya saing Indonesia mengalami penurunan yang cukup tajam, dari urutan ke 31 tahun 1998 menjadi urutan ke 37 tahun 1999. Jika dibandingkan dengan peringkat serupa pada tahun 1997 yang berada di urutan 15, peringkat itu anjlok 22 angka $^{10}$.

\footnotetext{
${ }^{7}$ Harian Kompas, Loc. cit.

${ }^{8}$ Ibid. halaman 8

${ }^{9}$ Harian Kompas, Ibid.

${ }^{10} \mathrm{Ibid}$, Tanggal 14 Juli 1999.
} 


\section{Grafik 3}

Daya Saing Global dan Kemudahan Berusaha di Indonesia Periode Tahun 2009 hingga 2017

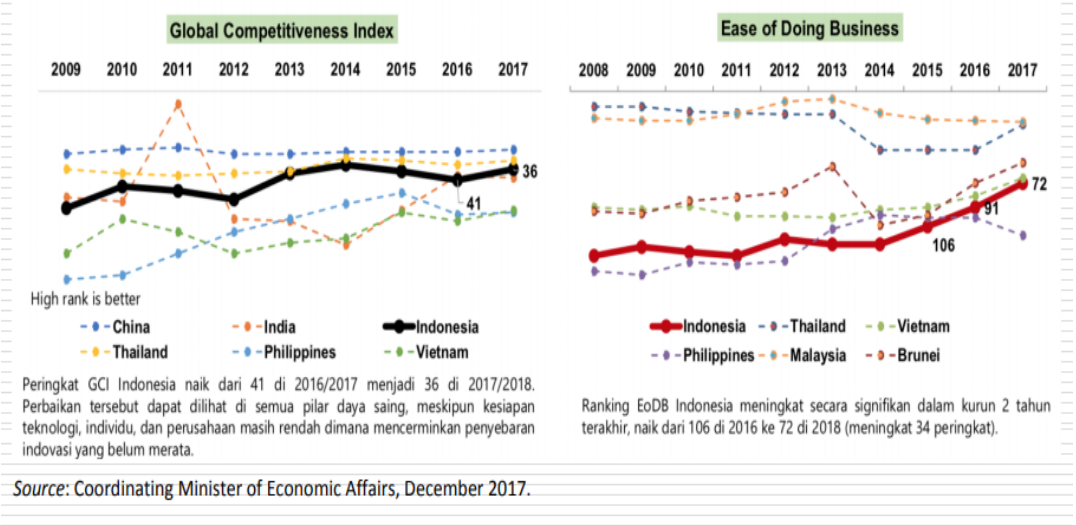

Peringkat daya saing global yang dipublikasikan World Economic Forum (WEF) tahun ini mengurutkan 59 negara berdasarkan potensi pertumbuhan ekonomi jangka menengah, dan dibuat berdasarkan survei terhadap hampir 4000 pejabat eksekutif bisnis di seluruh dunia. Peringkat itu, menurut WEF yang menjadi tuan rumah pertemuan para pimpinan bisnis dan politik di Davos, Swiss, setiap tahunnya, disusun berdasarkan penilaian terhadap delapan keriteria. Kedelapan kriteria tersebut meliputi antara lain : keterbukaan terhadap perdagangan dan investasi, peran negara, keuangan, infra struktur, teknologi, manajemen, buruh, dan kelembagaan ${ }^{11}$.

Pada sisi lain, perkembangan nilai ekspor non migas Indonesia ke 24 negara tujuan utama, selama April - Maret 1998/1999 mengalami penurunan 9,71 persen. Secara absolut penurunan nilai ekspor tesebut sebesar 34, 93 miliar dollar AS dibanding periode April - Maret 1995/1996 yang pernah mencapai 38,69 miliar dollar AS. ${ }^{12}$ Pertumbuhan ekonomi Indonesia hingga tahun 2000 diperkirakan masih sangat rendah. Demikian pula pertumbuhan nilai ekspor dan impor sebagai indikasi pulihnya perekonomian nasional diperkirakan masih sangat lemah. Setelah kontraksi sebesar 20,9\% tahun 1998 . Ekspor diperkirakan hanya tumbuh $0,2 \%$ tahun ini dan $0,6 \%$ tahun 2000 , sedangkan impor yang mengalami kontraksi 28,2 persen diprediksikan akan tumbuh 2,8\% pada tahun 1999 dan turun kembali sebesar $0,9 \%$ tahun $2000^{13}$.

\footnotetext{
${ }^{11}$ Ibid, Tanggal 18 Juli 1999.

${ }^{12}$ Laporan Bulanan Depperidag Tanggal 8 juli 1999, Dikutip dari Harian Kompas Tanggal 9 Juli 1999.

${ }^{13}$ Harian Kompas, Loc.cit.
} 
Keadaan ekonomi yang sulit dan belum stabilnya kondisi sosial politik dalam negeri, merupakan salah satu faktor yang mempengaruhi pertimbangan para investor dalam menanamkan modalnya di Indonesia disamping faktor-faktor lain yang menjadi daya tarik, seperti telah disebutkan oleh World Economic Forum (WEF). Daya tarik lain yang dapat mengundang para investor dalam menanamkan modalnya, diantaranya adalah beban tarif pajak yang diberlakukan oleh negara. Pemberian fasilitas dan insentif pajak dengan kebijakan kombinasi tarif pajak yang bervariasi yang diterapkan oleh beberapa negara tetangga seperti Thailand, Singapura, Vietnam, dan beberapa negara lainnya terbukti sangat efektif dalam menarik para investor untuk berinvestasi di negara-negara tersebut. Dalam hal ini pajak merupakan salah satu instrumen penting kebijaksanaan fiskal suatu negara dalam menentukan pertumbuhan ekonomi dan kelangsungan pembiayaan pembangunan $^{14}$.

Dengan demikian, rezim pemerintahan baru Indonesia -setelah reformasi yang dimotori oleh mahasiswa pada tahun 1998- yang telah terbentuk dihadapkan pada permasalahan yang cukup pelik, mengingat bahwa dalam setiap kebijakan yang diambil diharapkan akan dapat memulihkan kondisi sosial, ekonomi maupun kondisi politik ke arah yang lebih baik. Arah reformasi ekonomi dengan prioritas kebijakan fiskal yang tepat akan sangat mendukung bagi terciptanya pertumbuhan ekonomi yang semakin baik dengan kemampuan untuk menghadapi persaingan global seperti halnya dihadapi pula oleh negaranegara lainnya.

\section{Keberlanjutan Kebijakan Pembaruan Sistem Perpajakan Nasional: Pajak sebagai Sumber Penerimaan Negara yang Bekelanjutan (Renewable Revenue Resources)}

Pada dekade tahun 1980-an, salah satu aspek yang menonjol dari kondisi politik ekonomi saat itu ialah berkurangnya sumber-sumber ekonomi yang diperlukan bagi pembangunan nasional, termasuk kelangsungan dalam melaksanakan program-program pemerintah seperti Repelita dan APBN. Keadaan demikian ini berbeda sekali dengan adanya boom minyak ditahun-tahun 1973/1974 dan tahun 1979/1980 $0^{15}$.

Dekade tahun 1980 terus menerus ditandai dengan merosotnya ekspor minyak bumi yang memukul ekonomi, setidak-tidaknya dari dua segi yaitu penerimaan devisa

${ }^{14}$ Pilat, D., F. Lee and B. van Aark (2002), "Production and the use of ICT: A sectoral perspective on productivity growth in the OECD Area”, OECD Economic Studies, No. 35. Halaman 67 
yang berkurang serta penerimaan anggaran negara yang merosot karena berkurangnya penerimaan pajak atas ekspor minyak bumi yang tingkatnya tinggi serta volumenya sebagai persentase dari total anggaran adalah yang terbesar dibandingkan dengan penerimaan pemerintah lainnya seperti pajak dan bantuan luar negeri ${ }^{16}$.

Dihadapkan pada kesulitan fiskal yang disebabkan menurunnya harga minyak dan meningkatnya cicilan bunga hutang, maka pemerintah melaksanakan kebijaksanaan penghematan anggaran pada awal tahun 1980-an, yakni meningkatkan penghasilan melalui reformasi sistem perpajakan baru pada tahun 1983-1985 dan mengusahakan kembali pengadaan pinjaman baru dari kreditur barat ${ }^{17}$.

Dari keadaan ekonomi yang kurang menentu dan adanya kenyataan bahwa banyaknya perundang-undangan perpajakan peninggalan jaman penjajahan yang tidak sesuai lagi dengan keadaan Indonesia yang sudah merdeka serta sistem perpajakan yang kurang mendukung iklim ekonomi yang semakin modern. Pemerintah berketetapan melaksanakan kebijaksanaan Pembaharuan Sistem Perpajakan Nasional (PSPN) yang berkepribadian Indonesia dan yang menampung aspirasi bangsa Indonesia.

Kebijakan Pemerintah yang demikian tersebut menunjukkan bahwa dalam kegiatan pembangunan nasional, hukum mulai mendapat peran sebagai sarana perubahan dan pembangunan. Hukum dalam hal ini sudah digunakan sebagai sarana perekayasa sosial ekonomi dan bahkan dengan memperbarui asas-asas hukum pajak tersebut menjadi sedemikian rupa sehingga menunjang rencana pembangunan sosial ekonomi jangka panjang (droit del' economic) $)^{18}$.

\section{Grafik 4.}

Penerimaan Pajak Pasca Reformasi Perpajakan Nasional Pertama Tahun1983 hingga Periode Ketiga Tahun 2015

\footnotetext{
${ }^{15}$ OECD (2014), Perspectives on Global Development 2014: Boosting Productivity to Meet the Middle-Income Challenge, OECD Publishing, Paris, http://dx.doi.org/10.1787/persp_glob_dev-2014-en. ${ }^{16}$ Syahrir, Ekonomi Politik dan Undang-undang Pajak, Prisma No. 4 Tahun 1985 halaman 35.

${ }^{17}$ Anwar Nasution, Perkembangan Perekonomian Indonesia 1978-1991 Dampak Jangka Pendek dan Implikasi Jangka Panjang, Prisma No. 9 Tahun 1991 halaman 41.

${ }^{18}$ Sunaryati Hartono menyebutkan bahwa makna pembaruan dan pembangunan hukum meliputi :

a. menyempurnakan (membuat) sesuatu yang lebih baik.

b. Mengubah agar menjadi lebih baik dan modern.

c. Mengadakan sesuatu yang sebelumnya belum ada, atau

d. Meniadakan sesuatu yang terdapat dalam sistem lama, karena tidak diperlukan dan tidak cocock dengan sistem yang baru.

Lihat dalam CFG. Sunaryati Hartono, Politik Hukum Menuju Satu Sistem Hukum Nasional, Penerbit Alumni, Bandung, 1991, halaman 80-98.
} 


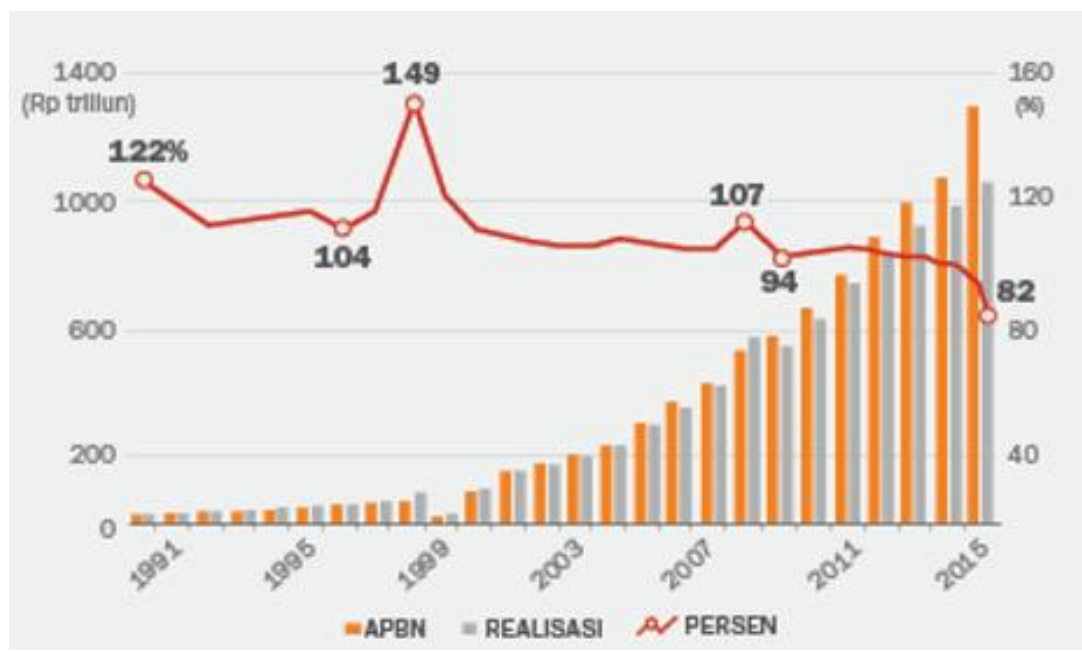

Sumber: diolah dari berbagai informasi dan sumber berita

Dengan adanya Pembaharuan Sistem Perpajakan Nasional (PSPN) diharapkan oleh pemerintah akan memberikan iklim yang baru bagi perekonomian nasional dan pembangunan bangsa yang semakin mandiri. Penerimaan pajak untuk APBN pada awal reformasi hingga pasca krisis finansial berdasarkan ilustrasi pada grafik no.4 di atas, terlihat sebesar Rp 120 Triliun, yaitu mencapai angka $82 \%$ dari penerimaan dalam negeri. Kecenderungan kenaikan penerimaan pajak yang konsisten dan signifikan tersebut merupakan salah satu harapan bagi adanya pembiyaan mandiri untuk pembangunan nasional $^{19}$.

Dengan pembiayaan yang lebih banyak memanfaatkan potensi nasional yang ada, baik yang berasal dari sektor produksi non migas tabungan nasional maupun dari bidang perpajakan itu sendiri. Pada sisi lain, adanya kebijakan Pembaruan Sistem Perpajakan Nasional (PSPN) ini menunjukkan kehendak pemerintah untuk melakukan pembaruan dan pembangunan hukum ${ }^{20}$.

Ditinjau dari segi ketatanegaraan, juga terlihat adanya perbedaan pokok mengenai pelaksanaan pemungutan pajak dijaman kolonial dan alam kemerdekaan dewasa ini. Kalau pada jaman kolonial pemungutan pajak semata-mata ditunjukan untuk memenuhi kepentingan penjajah, dalam alam kemerdekaan pemungutan pajak merupakan perwujudan partisipasi anggota masyarakat dalam memenuhi keperluan negara dan pembangunan

${ }^{19}$ Tambunan, Tulus, 1998, Krisis Ekonomi dan Masa Depan Reformasi, Penerbit LPFE UI, Jakarta, halaman 98

${ }^{20}$ CFG. Sunaryati Hartono, sejarah Perkembangan Hukum Indonesia Menuju Sistem Hukum Nasional, Makalah, 1991, sebagaimana dikutip oleh Djuhaendah Hasan Dalam Bukunya "Lembaga-lembaga 
nasional guna tercapainya keadilan sosial dan kemakmuran yang merata, baik materil maupun spiritual. ${ }^{21}$

Rochmat Soemitro dalam tulisannya yang berjudul "Pembaharuan Perpajakan Ditinjau Dari Segi Hukum", menyebutkan ada beberapa alasan yang menjadi sebab pembaharuan perundang-undangan perpajakan. Beberapa alasan tersebut antara lain adalah $:{ }^{22}$

a. Dasar falsafah atau ideologi yang dijadikan sebagai landasan perundangundangan pajak kolonial tidak cocok dengan falsafah Pancasila.

b. Struktur Organisasi pemerintah kolonial berbeda dengan struktur dan organisasi negara hukum Republik Indonesia yang merdeka dan berdaulat.

c. Situasi, kondisi serta aspirasi rakyat Indonesia pada waktu penjajahan adalah berbeda dengan waktu sekarang.

d. Keadaan ekonomi rakyat Indonesia pada jaman pemerintahan kolonial berbeda dengan waktu sekarang.

e. Tujuan pajak jaman kolonial untuk kepentingan penguasa/penjajah sematamata, sehingga pajak dimata rakyat merupakan momok yang selalu ditentang karena membebani.

Disamping beberapa faktor sebagaimana telah disebutkan di atas masih ada faktor-faktor lain, yaitu yang berkaitan dengan situasi perekonomian nasional maupun internasional pada saat itu yang akhirnya mendorong pemerintah Indonesia untuk mengambil inisiatif menggali dan memobilisasi berbagai sumber pembiayaan pembangunan nasional secara mandiri ${ }^{23}$.

Dari semua uraian diatas, secara lebih singkat dapat dideskripsikan bahwa tujuan dari pembaruan sistem perpajakan ( tax reform ) tidak lain adalah "penyederhanaan, penertiban dan kepastian hukum" sistem perpajakan. Penyederhanaan meliputi jenis pajak, jumlah pajak, cara pemungutannya dan juga mengenai materinya, sedangkan yang dimaksud dengan penertiban itu sendiri lebih dititikberatkan mengenai manusia-

Jaminan Kebendaaan Bagi Tanah dan Benda Lain Yang Melekat Pada Tanah Dalam Konsepsi Penerapan Asas Pemisahan Horizontal”, Penerbit Citra Aditya Bhakti, Bandung 1996, halaman 2

${ }^{21}$ Salamun A.T., "Pembaruan Dibidang Perpajakan Suatu Tinjauan Umum”, Prisma No. 4 Tahun 1985, halaman 4

${ }^{22}$ Rocmat Soemitro, Pembaharuan Perpajakan Ditinjau dari Segi Hukum. Prisma No. 4 Tahun 1985. halaman 87

${ }^{23}$ Anwar Nasution, op.cit, halaman 42 
manusianya, baik berkenaan dengan pejabat pajak maupun wajib pajaknya sehingga akan memberikan pengaruh dan akibat langsung bagi peningkatan hasil-hasil pajak yang masuk kas negara ${ }^{24}$.

Dengan adanya tax reform pada tahun 1984 dan dilanjutkan dengan beberapa kebijakan pembaruan perpajakan hingga periode tahun 2009, pemerintah selanjutnya juga melakukan revisi dan perubahan atas undang-undang perpajakan untuk mendorong dan memberikan iklim yang baru bagi perekonomian nasional dan pembangunan bangsa yang semakin mengandalkan pada kemandirian dalam pembiayaan pembangunan. Dengan demikian pembiayaan pembangunan nasional lebih banyak memanfaatkan potensi yang ada, baik yang berasal dari sektor produksi non migas, tabungan nasional maupun dari bidang perpajakan itu sendiri.

Adanya keberlanjutan pembaruan sistem perpajakan serta penetapan undangundang perpajakan, dimaksudkan supaya beban pajak yang dikenakan pada rakyat akan semakin memenuhi rasa adil dan wajar, sehingga disatu pihak dapat mendorong wajib pajak melaksanakan dengan kesadaran kewajiban dalam membayar pajak dan pada pihak lain untuk lebih menutup lubang ( loopholes ) yang selama ini masih terbuka bagi mereka yang mencoba menghindari pajak. Kebijakan reformasi pajak yang dilakukan Pemerintah, dengan demikian akan menciptakan suatu sistem perpajakan yang sederhana dan mudah dimengerti oleh setiap orang, sistem perpajakan yang semakin didasarkan syarat-syarat dan prinsip keadilan, kewajaran, serta memberikan kepastian hukum bagi Wajib Pajak.

\section{Sinergi Fungsi Pajak sebagai Instrumen Kebijakan Fiskal: Menjaga Stabilitasi Daya Saing Investasi dan Ketahanan Ekonomi Nasional di Tengah Pandemi Covid-19}

Sebagai sumber pendapatan negara, pajak memiliki tiga fungsi, yaitu : pertama, sebagai salah satu sumber penerimaan pemerintah yang dapat digunakan untuk membiayai kegiatan-kegiatan pembangunan, dalam hal ini pajak mempunyai fungsi budgeter. Kedua, pajak dapat berperan untuk mengatur alokasi sumberdaya, distribusi pendapatan, dan konsumsi atau umum dikenal dengan apa yang dinamakan sebagai fungsi regulasi pajak. Ketiga, pajak berfungsi sebagai stabilitas ekonomi Dari fungsi-fungsi pajak sebagai instrumen kebijakan fiskal sebagaimana telah disebutkan itu pada umumnya kebijakan-

${ }^{24}$ Salamun A.T., loc.cit. 
kebijakan perpajakan yang dilakukan oleh pemerintah selalu diarahkan untuk memenuhi ketiga fungsi tersebut secara simultan ${ }^{25}$.

Pajak dalam pelaksanaan kegiatan pembangunan mempunyai fungsi yang amat strategis. Pajak tidak hanya merupakan sumber keuangan negara yang digunakan untuk public investment, tetapi fungsi pajak juga dapat digunakan untuk mengendalikan kebijaksanaan negara yang lebih umum dikenal sebagai fungsi budgetair dan fungsi regulair. Disinilah sebenarnya pajak juga mempunyai peranan dalam korelasi antara pemerintah sebagai pelayan publik dengan masyarakat sebagai pendukung pelaksanaan pembangunan negara ${ }^{26}$.

Secara dikotomis, fungsi pajak dapat dibedakan menjadi 2 kelompok besar, yaitu fungsi budgetair dan fungsi regulair. Rochmat Soemitro memberikan pengertian fungsi budgetair adalah fungsi yang letaknya disektor publik, dan pajak merupakan suatu alat untuk memasukkan uang sebanyak-banyaknya ke dalam kas negara, yang pada gilirannya akan dikeluarkan untuk membiayai pengeluaran-pengeluaran negara. Fungsi budgetair pajak yang digunakan sebagai sarana pemerintah untuk memasukkan pendapatan sebanyak-banyaknya ke dalam kas negara guna membiayai pembangunan, merupakan lingkup kebijakan pemerintah yang berkaitan dengan hukum ekonomi pembangunan ${ }^{27}$.

Fungsi regulair adalah fungsi dimana pajak dipergunakan sebagai alat untuk mencapai tujuan-tujuan tertentu yang letaknya diluar bidang keuangan negara. Secara konkrit fungsi kedua ini terwujud dalam bentuk peningkatan atau penurunan tarif untuk memberikan insentif ataupun disinsentif agar tujuan-tujuan pemerintah tersebut dapat tercapai. Fungsi regulair secara substantif sebenarnya merupakan cara tertentu untuk merekayasa kondisi sosial ekonomi masyarakat. Pada sisi lain, fungsi regulair pajak yang ditempuh pemerintah bertujuan untuk mencapai kesejehteraan ekonomi dan merekayasa kondisi sosial ekonomi masyarakat yang lebih adil dan merata termasuk dalam bidang hukum ekonomi sosial. Oleh Miyasto, dalam kebijakan fiskal, pajak juga dapat berfungsi sebagai stabilitasi ekonomi ${ }^{28}$.

${ }^{25}$ Miyasto, Optimalisasi Penerimaan Pajak, Makalah Seminar Perpajakan, Tgl 18 Juni, Fisip UNDIP Semarang, halaman 8.

${ }^{26}$ Rimsky Judisseno, Pajak dan Strategi Bisnis, Penerbit P.T. Gramedia, Jakarta, 1997, halaman43.

${ }^{27}$ Rochmat Soemitro, Pajak dan Pembangunan, Eresco, Bandung, 1986, halaman 108-109.

${ }^{28}$ Miyasto, loc.cit. 


\section{Grafik}

\section{Ilustrasi Fungsi Pajak sebagai Instrumen bagi Kebijakan Fiskal}

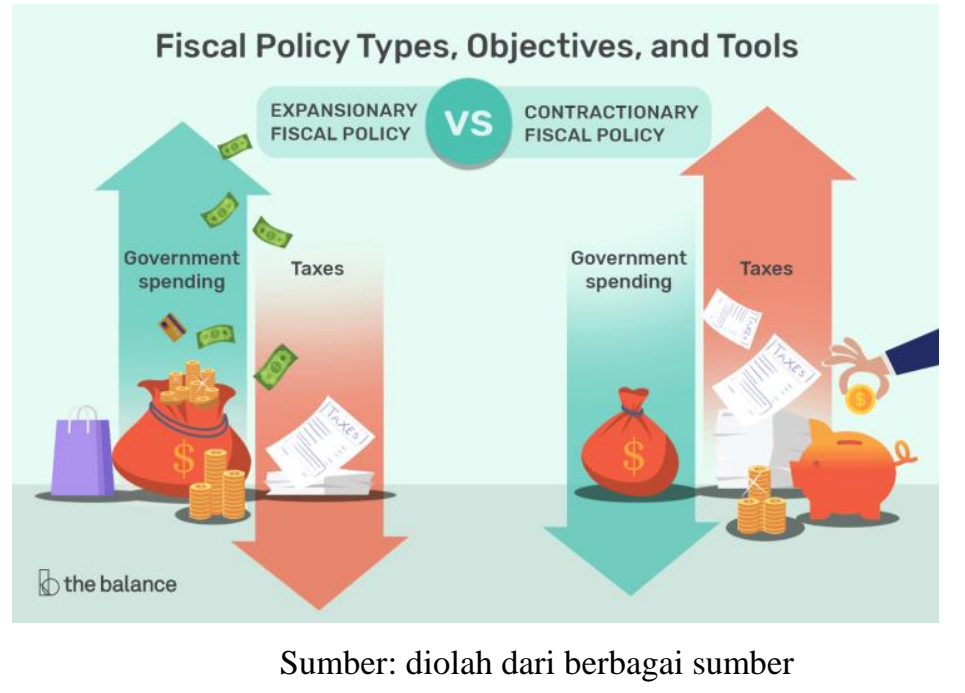

Sebagai suatu alat pembangunan, kebijaksanaan fiskal dapat efektif berjalan apabila dalam pelaksanaannya didasarkan atas kombinasi tarif-tarif pajak yang tinggi yang dikenakan pada jenis pajak langsung maupun pajak tidak langsung. Pengenaan tarif pajak yang tinggi ini dapat diterapkan misalnya untuk menghambat tingkat pengeluaran yang bersifat konsumtif, menghambat laju impor atau melakukan proteksi/perlindungan terhadap produk-produk dalam negeri yang belum siap untuk melakukan persaingan dengan produk luar.

Kebijakan fiskal dengan kombinasi tarif-tarif pajak tersebut harus pula didasarkan pada suatu fleksibilitas yang berada dalam sistem pengenanaan pajak-pajak, yaitu berupa pembebasan pajak-pajak dan pemberian intensif-intensif atau dorongandorongan untuk merangsang privat investment sebagaimana diharapkan. Dengan demikian kebijaksanaan fiskal yang diambil pemerintah dengan melalui penentuan Anggaran Pendapatan dan Belanja Negara (APBN) ini disamping mempunyai fungsi budgetair, juga mempunyai fungsi mengatur kegiatan-kegiatan ekonomi kearah yang dikehendaki.

Pada umumnya kebijaksanaan fiskal digunakan untuk mengatur stabilitas ekonomi dengan sasaran utama untuk mencapai tingkat pertumbuhan ekonomi tinggi tanpa disertai dengan gejolak-gejolak inflasi dan resesi. Dalam mencapai tujuan-tujuan tersebut, kebijaksanaan fiskal selalu didampingi dengan kebijaksanaan-kebijaksanaan lain seperti kebijaksanaan moneter dan kebijaksanaan-kebijaksanaan sektor riil. Ada tiga instrument 
utama dari kebijaksanaan fiskal, yaitu sebagai berikut: ${ }^{36}$ Pajak (tax), pengeluaran Pemerintah (government expenditure) dan Pinjaman-pinjaman (loans)

Berdasarkan sifat dari kebijaksanaan fiskal, maka kebijaksanaan fiskal ini dapat dikelompokkan menjadi dua golongan, yaitu: kebijaksanaan fiskal yang bersifat ekspansif dan kebijaksanaan fiskal yang bersifat kontraksi. Penggunaan masing-masing kebijaksanaan tersebut sangat tergantung dari kondisi ekonomi yang dihadapi masyarakat. Apabila perekonomian berada pada kondisi resesi, maka pemerintah dapat melakukan kebijaksanaan fiskal yang bersifat ekspansif. Melalui kebijaksanaan ini diharapkan akan memacu pertumbuhan ekonomi kearah yang lebih tinggi ${ }^{37}$.

Suatu tindakan kebijaksanaan fiskal yang bersifat kontraksi dilakukan oleh pemerintah diarahkan untuk mengerem laju pertumbuhan ekonomi. Kebijaksanaan ini dilakukan oleh pemerintah, apabila kondisi ekonomi negara berada dalam keadaan inflasi (overheating economy). Berlawanan dengan kebijaksanaan fiskal yang ekspansif, kebijaksanaan fiskal yang kontraksi dilakukan dengan surplus spending, yaitu dengan cara melakukan peningkatan tarif maupun penerimaan pajak, menurunkan pengeluaran pemerintah atau melakukan tindakan kedua-duanya secara bersamaan ${ }^{29}$.

Insentif pajak sebagai salah satu sarana stimulus dalam mendorong penanaman modal bukan merupakan faktor tunggal yang mempengaruhi minat investor untuk menanamkan modal. Dengan melihat keterkaitan faktor insentif pajak (khususnya pajak penghasilan) terhadap kegiatan ekonomi, Guritno Mangkoesoebroto menganalisis bahwa pembebanan pajak akan berpengaruh terhadap konsumsi barang, pengeluaran konsumsi dan tabungan, motivasi menabung, pemilihan bentuk tabungan, penawaran tenaga kerja, dan sebagainya ${ }^{30}$.

Pembebanan pajak juga akan berpengaruh terhadap investasi, karena pajak tersebut akan mengurangi hasil investasi yang dilaksanakan. Investasi merupakan tindakan yang mengandung resiko, sebab investasi mungkin memberikan keuntungan sebagaimana yang diharapkan, tetapi juga mungkin menghadapi kegagalan berupa kerugian. Beban membayar pajak penghasilan akan menyebabkan orang enggan untuk melakukan investasi

${ }^{36}$ Chidir Ali, “Hukum Pajak Elementer”, Eresco, Bandung, 1993, halaman 37.

${ }^{37}$ Miyasto, "Kemandirian Pembiayaan Pembangunan", Pusat Pengkajian Perpajakan dan Keuangan, Jakarta, 1993, halaman 58.

${ }^{29}$ Guritno Mangkoesoebroto, Ekonomi Publik, Badan Penerbit Fakultas Ekonomi UGM, Yogyakarta, 1993, halaman 225-234.

${ }^{30}$ Guritno Mangkoesoebroto, op. cit., halaman 234. 
apabila pajak tersebut mengakibatkan turunnya investasi. Tentu saja akan timbul kondisi sebaliknya apabila pembebanan pajak diperkecil. Hal yang terakhir ini akan mengakibatkan penghasilan bersih investor menjadi lebih besar, sehingga semakin merangsang untuk menanamkan modal ${ }^{31}$.

Sekalipun insentif pajak bukan merupakan satu-satunya faktor yang mempengaruhi pilihan investor untuk menanamkan modal, namun tidak dapat dipungkiri bahwa kebijakan perpajakan akan mempengaruhi pilihan investor untuk menanamkan modal atau tidak. Dengan mengasumsikan bahwa faktor-faktor lain yang mempengaruhi penanaman modal tidak berubah (ceteris paribus), maka kebijakan pemerintah dalam bidang perpajakan yang bersifat memberikan insentif, misalnya dengan memberikan fasilitas tax exemption, accelerated depreciation initial loss, maupun insentif lainnya akan meningkatkan minat investor untuk menanamkon modal ${ }^{32}$.

Sebagai salah satu instrumen kebijakan fiskal, politik hukum perpajakan akan memberikan arah kondisi masyarakat yang ingin dicapai. Politik hukum perpajakan yang implementasinya tertuang dalam kebijakan publik akan menimbulkan dampak yang luas. Guritno Mangkoesoebroto mengemukakan analisisnya bahwa pembebanan pajak penghasilan akan mempengaruhi pola konsumsi masyarakat, pengeluaran untuk konsumsi, untuk tabungan, pilihan untuk menabung investasi, serta penyediaan tenaga kerja ${ }^{33}$.

Salah satu teori yang melakukan pengkajian terhadap pembebanan pajak adalah teori incidens pajak (tax incidence theory). Teori ini melihat bahwa beban pajak tidak hanya terbatas secara legal formal saja tetapi mengkaji pembebanan pajak pada tingkat yang lebih substantive, misalnya, pajak penghasilan atas badan, walaupun pajak dikenakan terhadap laba badan yang menjadi wajib pajak, tetapi sebenarnya bukan perseroannya sendiri yang secara substantif akan menjadi penanggung beban pajak, karena badan ini hanyalah bentuk usaha ${ }^{34}$.

Dalam hal adanya tujuan untuk mendorong adanya penanaman modal, sumber modal yang akan dinvestasikan dapat berasal dari pemerintah (public investment) maupun berasar dari dana masyarakat (private investment). Komposisi besaran porsi public investment apabila dibandingkan dengan private investment, model yang dikembangkan oleh Rostow dan Musgrave dapat menjadi alternatif yang dinilai paling lazim. Rostow dan

\footnotetext{
${ }^{31}$ Op.cit., halaman 235-264.

${ }^{32}$ Loc.cit.

${ }^{33}$ Ibid. halaman 289.
} 
Musgrave menghubungkan porsi pemerintah untuk menanamkan modal dengan tahap perkembangan ekonomi yang dapat dibagi menjadi tahap awal, tahap menengah dan tahap lanjut. Pada tahap awal perkembangan ekonomi, porsi investasi publik terhadap total investasi cukup besar. Pada tahap ini pemerintah harus menyediakan sarana dan prasarana publik $^{35}$.

Kebijakan Pemerintah dalam rangka mengalokasikan dan merencanakan pembelanjaan sumber penerimaan negara dimaksudkan untuk mencapai tujuan pembangunan. Pada sisi lain perencanaan kebijakan pemerintah bertujuan untuk mendapatkan dana-dana yang sangat dibutuhkan untuk membiayai pengeluaranpengeluaran pemerintah didasarkan pada kebijaksanaan fiskal. Melalui kebijaksanaan fiskal tersebut dapat dilihat fungsi alokasi anggaran belanja negara terhadap sumbersumber dana yang ditujukan untuk pengadaan kebutuhan barang-barang bagi kepentingan umum secara seimbang, fungsi distribusi untuk menyesuaikan pembagian tingkat pendapatan dan kesejahteraan masyarakat dan fungsi stabilitasi guna lebih menjamin dan mempertahankan tingkat pertumbuhan ekonomi secara cepat dan mantap untuk kegiatan pembangunan dan peningkatan pertumbuhan negara.

Dengan adanya pembebanan pajak secara adil, ada harapan bahwa kebijakan fiskal yang menggunakan instrumen pajak dan berimbas pada masyarakat tersebut akan bersifat netral dan mendorong stabilitasi ekonomi dan fiskal. Mengingat bahwa pajak dapat juga mempunyai fungsi regulasi, maka prinsip keadilan dalam pembebanan pajak tersebut terkadang sengaja disimpangi untuk memberikan rangsangan dalam merekayasa kondisi tertentu dalam masyarakat. Implikasi dari tindakan tersebut, antara lain dimaksudkan untuk mendorong agar orang yang memiliki modal mau menanamkan modalnya ke sektor-sektor produksi tertentu, pemerintah memberikan pembebanan pajak penghasilan atas penghasilan yang diperoleh dari penanaman modal ${ }^{36}$.

\section{Simpulan}

Berdasarkan hasil penelitian dan pembahasan, diperoleh kesimpulan sebagai berikut: a). fungsi pajak sebagai instrumen kebijakan fiskal, dengan kombinasi fungsi mengatur (regulerend) dan stabilitasi ekonomi untuk menjaga kondisi kontraksi dan

\footnotetext{
${ }^{34}$ Ibid. Halaman 182

${ }^{35}$ Guritno Mangkoesoebroto, op.cit. halaman 170-171.

${ }^{36}$ Rimsky Judiseseno, Ibid, halaman 10.
} 
relaksasi ekonomi nasional, mempunyai fleksibilitas untuk penerimaan negara (budgetair) yang berkelanjutan (sustainable budged income); b). Keberhasilan kebijaksanaan fiskal untuk meningkatkan daya saing investasi dan mengantisipasi pelemahan ekonomi global dapat dilihat dari fungsi alokasi anggaran belanja negara untuk biaya pemerintah dan kepentingan umum dalam keadaan seimbang, serta fungsi distribusi untuk kesejahteraan masyarakat dengan tetap menjaga stabilitasi pertumbuhan ekonomi yang mendukung pembangunan Nasional; c). Kebijakan reformasi pajak berkelanjutan yang dilakukan Pemerintah bertujuan untuk menciptakan sistem perpajakan yang sederhana, mudah dimengerti oleh setiap orang, dan sistem perpajakan yang semakin didasarkan syarat-syarat dan prinsip keadilan, kewajaran, serta memberikan kepastian hukum.

Rekomendasi dari hasil penelitian dan pembahasan ini adalah: a). Pemerintah perlu membuat kebijakan fiskal dan menciptakan inovasi regulasi perpajakan yang dapat mewujudkan keseimbangan baru antara kepentingan-kepentingan konsumen, pengusaha, masyarakat, dan pemerintah. b). Pemerintah harus membuat kebijakan perpajakan yang mampu mempengaruhi minat investor untuk menanamkan modal tidak bersifat tunggal dan menciptaan iklim yang kondusif untuk menanamkan modal harus meliputi penataan faktorfaktor tersebut secara simultan dan berkelanjutan. dan c). Kebijakan reformasi pajak yang dilakukan Pemerintah yang berkelanjutan harus mampu menciptakan suatu sistem perpajakan yang sederhana,mudah dimengerti oleh setiap orang, didasarkan syarat-syarat dan prinsip keadilan, kewajaran, dan memberikan kepastian hukum bagi Wajib Pajak.

\section{E. Daftar Pustaka}

Asikin, A., Tika Noorjaya, Y. Himawati, 1990, Pajak, Citra dan Bebannya, Pokokpokok Pikiran Salamun AT, Bina Rena Pariwara, Jakarta

Ali, Chidir, 1998, "Hukum Pajak Elementer”, Eresco, Bandung.

Hartono, CFG. Sunaryati, 1991, Politik Hukum Menuju Satu Sistem Hukum Nasional, Penerbit Alumni, Bandung

Hartono, Sunaryati, C.F.G., 1994, Beberapa Masalah Transnasional dalam Penanaman Modal Asing di Indonesia, Binatjipta

Hasan, Djuhaendah, 1996, "Lembaga-lembaga Jaminan Kebendaaan Bagi Tanah dan Benda Lain Yang Melekat Pada Tanah Dalam Konsepsi Penerapan Asas Pemisahan Horizontal”, Penerbit Citra Aditya Bhakti, Bandung 1996

Judisseno, Rimsky, 1997, Pajak dan Strategi Bisnis, Penerbit P.T. Gramedia, Jakarta

Kusumaatmadja, Mochtar, 1976, Hukum, Masyarakat dan Pembinaan Hukum Nasional, Binacipta, Bandung

Mangkoesoebroto, Guritno, 1993, Ekonomi Publik, Badan Penerbit Fakultas Ekonomi UGM, Yogyakarta 
Miyasto, 1993, “Kemandirian Pembiayaan Pembangunan”, Pusat Pengkajian Perpajakan dan Keuangan, Jakarta

Panglaikym, J., 1984, Investasi Langsung Jepang di Kawasan ASEAN, Pengalaman Indonesia, Andi Offset dan Maruzen Asia, Yogyakarta-Singapura,

SR., Soemarsono, 1990, Prospek Pajak Penghasilan dan Pajak Pertambahan Nilai dalam Pelita V, PT Bina Rena Pariwara, Jakarta

Soemitro, Rochmat, 1998, "Pajak dan Pembangunan", Eresco, Bandung

Tambunan, Tulus, 1998, Krisis Ekonomi dan Masa Depan Reformasi, Penerbit LPFE UI, Jakarta

A.T., Salamun, 1985, Pembaharuan Di Bidang Perpajakan Suatu Tinjauan Umum, Prisma No. 4 Tahun 1985

Budiono, Tri, 1996., “Memacu Investasi Dengan Instrumen Pajak”, Majalah Refleksi Hukum, Fakultas Hukum UKSW, Oktober

Hartono, Sunaryati, CFG. , 1991, Sejarah Perkembangan Hukum Indonesia Menuju Sistem Hukum Nasional, Makalah

Harian Kompas Tanggal 1 Juli 1999

Harian Kompas Tanggal 9 Juli 1999, Laporan Bulanan Depperidag Tanggal 8 Juli 1999

Harian Kompas, Tanggal 14 Juli 1999. 18 Juli 1999

https://katadata.co.id/berita/2019/05/23/menko-darmin-semua-menderita-akibat-perangdagang

Miyasto, Optimalisasi Penerimaan Pajak, Makalah Seminar Perpajakan, Tgl 18 Juni, 1997, FISIP UNDIP, Semarang

Nasution, Anwar, 1991, Perkembangan Perekonomian Indonesia 1978-1991 Dampak Jangka Pendek dan Implikasi Jangka Panjang, Prisma No. 9 Tahun 1991

OECD, 2014, Perspectives on Global Development 2014: Boosting Productivity to Meet the Middle-Income Challenge, OECD Publishing, Paris http://dx.doi.org/10.1787/persp_glob_dev-2014-en.

Pilat, D., F. Lee and B. van Aark (2002), "Production and the use of ICT: A sectoral perspective on productivity growth in the OECD Area", OECD Economic Studies, No. 35

Prasetyantoko, A., 2019, "Analisis Ekonomi: Analisis Ekonomi Memahami Transmisi Krisis" dikutip dari laman https://Kompas.Id/Baca/Utama/2019/09/10/Memahami-Transmisi-Krisis/

Syahrir, Ekonomi Politik dan Undang-undang Pajak, Prisma No. 4 Tahun 1985

Soemitro, Rocmat, Pembaharuan Perpajakan Ditinjau dari Segi Hukum. Prisma No. 4 Tahun 1985. hlm. 87.

Wee, The Kian, 1996, Kenaikan Laju Konsumsi dan Investasi Pemicu Lompatan Pertumbuhan Ekonomi, Kompas Tanggal 30 April 1996. 